\title{
KESULITAN SISWA SEKOLAH DASAR \\ PADA MATERI NILAI TEMPAT \\ MATA PELAJARAN MATEMATIKA DI KELAS I SD
}

\author{
Dessi Selvianiresa \\ Pendidikan Dasar, Universitas Pendidikan Indonesia \\ dessiselvianiresa92@gmail.com
}

\begin{abstract}
The goal of mathematics in elementary schools in general is that students can solve problems related to mathematics. In mathematics, students not only emphasize the cognitive process alone, but are expected to form the student's personality so that they can be skilled at using mathematics in their daily life. The basis of mathematics became an important benchmark in understanding mathematical material. As in the mathematical material is the value of place that became the basis of students in studying the wider mathematics again. When students experience difficulty in place value, it will also be fatal in higher materials, such as counting operations. The study was conducted in one school in Bandung, with the subject of the first grade students of SD, amounting to 47 students. Based on the results of the analysis, students are still difficult in placing the numbers according to the value of place. This also resulted, when the child was given a matter of counting operations, the students experienced errors writing numbers and counting them. For that, it takes the role of teachers in designing learning that can facilitate students in understanding the material. In addition, teachers need to predict some errors of likely student answers, so teachers can quickly provide solutions and actions appropriately.
\end{abstract}

Keywords: Place Value, Student Error Answers

\begin{abstract}
ABSTRAK
Tujuan matematika di Sekolah Dasar secara umum ialah agar siswa dapat memecahkan masalah yang berhubungan dengan matematika. Dalam matematika, siswa tidak hanya menekankan pada proses kognitifnya saja, melainkan diharapkan dapat membentuk kepribadian siswa sehingga dapat terampil menggunakan matematika dalam kehidupan sehari-harinya. Dasar matematika pun menjadi patokan penting dalam memahami materi matematika. Seperti pada materi matematika yaitu nilai tempat yang menjadi dasar siswa dalam mempelajari matematika yang lebih luas lagi. Ketika siswa mengalami kesulitan nilai tempat, maka akan berakibat fatal pula pada materi yang lebih tinggi lagi, misalnya operasi hitung. Penelitian dilakukan di salah satu sekolah di Bandung, dengan subjek siswa kelas I SD yang berjumlah 47 siswa. Berdasarkan hasil analisis, siswa masih kesulitan dalam menempatkan bilangan sesuai nilai tempatnya. Hal ini berakibat pula, ketika anak diberi soal operasi hitung
\end{abstract}


penjumlahan, siswa mengalami kesalahan menulis bilangan dan menghitungnya. Untuk itu, dibutuhkan peranan guru dalam merancang pembelajaran yang dapat memudahkan siswa dalam memahami materi. Selain itu, guru perlu memprediksi beberapa kesalahan jawaban siswa yang kemungkinan akan muncul, sehingga guru cepat dapat memberikan solusi dan tindakan dengan tepat.

Kata Kunci : Nilai Tempat, Kesalahan Jawaban Siswa

\section{A. PENDAHULUAN}

Pembelajaran matematika di sekolah dasar merupakan mata pelajaran yang wajib dipelajari siswa. Matematika mempunyai manfaat yang bisa siswa dirasakan sendiri, khususnya di kehidupan siswa. Tujuan pembelajaran matematika di SD dapat dilihat di dalam kurikulum tingkat satuan pendidikan (BSNP, 2006:30), dinyatakan bahwa mata pelajaran matematika selain bertujuan untuk menekankan pada penataan nalar dan pembentukan sikap siswa serta memberikan tekanan pada keterampilan dalam penerapan, matematika juga memuat tujuan khusus yaitu: (1) menumbuhkan dan mengembangkan keterampilan berhitung sebagai latihan dalam kehidupan sehari-hari, (2) menumbuhkan kemampuan siswa, yang dapat dialihgunakan melalui kegiatan matematika, (3) mengembangkan kemampuan dasar matematika sebagai bekal belajar lebih lanjut, (4) membentuk sikap logis, kritis, cermat, kreatif dan disiplin. Dari tahun ke tahun, matematika berkembang semakin meningkat sesuai dengan tuntutan zaman yang mendorong manusia untuk lebih kreatif dalam mengembangkan atau menerapkan matematika sebagai ilmu dasar. Mata pelajaran Matematika sebagai ilmu dasar (basic of science) berkembang pesat, baik materi maupun kegunaanya di dunia ilmu pengetahuan dan teknologi. Dalam mengimbangi kemajuan tersebut diharapkan siswa mampu merespon dengan berbagai sikap kritis, kreatif, dan menyadari bahwa matematika itu penting bagi kehidupannya. Misalnya pada materi nilai tempat. Materi tersebut menjadi dasar dalam mempelajari materi yang lebih luas lagi, seperti operasi hitung. Walaupun materi tersebut merupakan dasar dan dapat dikatakan mudah, tetapi kadang masih banyak siswa yang mengalami berbagai kesulitan dalam mencerna atau memahami konsep-konsep matematika tersebut. Siswa sekolah dasar masih kesulitan dalam menuliskan lambang bilangan, pemahaman nilai tempat, bahkan masih kesulitan dalam operasi hitungnya. 
Misalnya 3 puluhan +1 satuan, masih banyak siswa menjawab 31 . Hal ini bahwa konsep nilai tempat belum benar-benar dikuasai oleh siswa.

Berdasarkan permasalahan tersebut, perlu adanya perhatian khusus bagi guru dalam melakukan pembelajaran agar tidak terjadi kesalahpahaman yang terus-menerus sehingga dari kekeliruan tersebut dapat berakibat kesalahan pada penerapan konsep-konsep lainnya yang merupakan pengembangan dari konsep tersebut. Guru dapat merancang pembelajaran dengan memberikan pembelajaran disertai metode atau media konkret, sehingga siswa dapat dengan mudah memahami nilai tempat. Hal ini karena menurut Ruseffendi (1992) bahwa pembelajaran yang efektif memperhatikan prinsip-prinsip belajar dan belajar akan berhasil jika diikuti dengan sungguh-sungguh oleh siswa. Pemilihan pendekatan pembelajaran sangat penting karena pendekatan yang dipilih akan ada kaitannya dalam menentukan metode mengajar yang sesuai. Selain itu, guru perlu memprediksi beberapa kemungkinan kekeliruan yang dihadapi siswa, beserta solusi terbaik yang dapat dilakukan dalam menghadapi kemungkinankemungkinan tersebut. Hal ini karena menurut Sumiaty dan Endang (2015) bahwa kendala atau kesalahan yang dialami siswa dapat disebabkan oleh sumber buku atau karena tidak terstruktur proses pembelajarannya, ataupun keduanya.

Dari uraian di atas dapat dirumuskan masalah sebagai berikut: Seperti apakah kesulitan siswa dalam mempelajari materi nilai tempat? Bagaimana hasil analisis antara prediksi dan kenyataan di lapangan? Faktor-faktor apa sajakah yang muncul dari kesalahan jawaban siswa?. Berdasarkan rumusan masalah, tujuan penelitian adalah: (1) mendeskripsikan kesulitan apa yang dialami siswa dalam mempelajari nilai tempat, (2) mendeskripsikan mengenai prediksi dan kenyataan di lapangan berdasarkan hasil jawaban-jawaban siswa, (3) mendeskripsikan faktor-faktor kesulitan yang dihadapi siswa sekolah dasar kelas I pada materi nilai tempat. Penelitian yang dilakukan diharapkan memberikan manfaat bagi berbagai pihak, baik secara teoritis yaitu menambah wawasan yang lebih luas tentang kesulitan belajar yang dihadapi siswa kelas I pada materi nilai tempat serta manfaat praktis bagi peneliti, lembaga, guru dan pembaca.

\section{B. LANDASAN TEORI}

\section{Pembelajaran Matematika di Sekolah Dasar}


Pembelajaran matematika di sekolah dasar memerlukan kemampuan guru dalam memahami karakteristik siswa sekolah dasar. Seperti yang dikemukakan oleh Suwangsih dan Tiurlina (2006: 25) bahwa pembelajaran matematika di sekolah dasar mempunyai beberapa karakteristik, yaitu:

a. pembelajaran matematika menggunakan metode spiral,

b. pembelajaran matematika bertahap,

c. pembelajaran matematika menggunakan metode induktif,

d. pembelajaran matematika menganut kebenaran konsistensi,

e. pembelajaran matematika hendaknya bermakna.

Pembelajaran matematika dengan metode spiral yaitu materi yang akan diajarkan selalu dihubungkan dengan materi yang telah siswa pelajari sebelumnya. Pemahaman mengenai materi yang dipelajarinya dapat dijadikan prasyarat dalam mempelajari materi selanjutnya. Pembelajaran matematika bertahap yaitu materi yang diajarkan sebaiknya dimulai pada konsep yang sederhana menuju ke konsep yang lebih sulit. Materi yang diajarkan pun dapat dimulai dari tahap konkret, semi konkret, dan akhirnya mencapai tahap abstrak. Pembelajaran matematika menggunakan metode induktif yaitu pembelajaran yang dimulai dengan memberikan konsep yang sederhana menuju ke konsep yang umum. Seperti diketahui di awal bahwa matematika merupakan ilmu deduktif, akan tetapi jika subjeknya adalah siswa SD, maka pembelajaran pun harus disesuaikan dengan perkembangan kemampuan berpikirnya.

Pembelajaran matematika menganut kebenaran konsistensi berarti pembelajaran matematika tidak memiliki pertentangan satu sama lain. Artinya bahwa setiap pernyataan yang dianggap benar merupakan hasil dari pernyataan sebelumnya yang telah diakui kebenarannya. Jadi, meskipun pembelajaran matematika SD menggunakan metode induktif, tetapi kebenarannya akan sama pula dengan pembelajaran matematika dengan metode deduktif. Pembelajaran matematika hendaknya bermakna berarti pembelajaran dalam matematika merupakan konsep yang tidak langsung jadi, melainkan perlu ada proses dalam mencapai konsep tersebut. Setiap konsep yang ada dalam matematika bukan merupakan konsep yang harus dihafal, melainkan perlu adanya pemahaman mengenai konsep tersebut melalui proses atau aktivitas belajarnya.

\section{Kesulitan Siswa SD dalam Matematika}


Menurut Sholeh (1998) bahwa siswa yang megalami kesulitan belajar disebabkan oleh hal-hal berikut, sebagai berikut.

a. Siswa tidak bisa menangkap konsep dengan benar.

b. Siswa tidak mengerti arti lambang-lambang.

c. Siswa tidak dapat memahami asal-usul suatu prinsip.

d. Siswa tidak lancar menggunakan operasi dan prosedur.

e. Ketidaklengkapan pengetahuan.

Berdasarkan hal di atas, banyak faktor yang menyebabkan siswa mengalami kesulitan dalam belajar matematika yang berakibat prestasi belajar matematika siswa belum mencapai hasil yang diharapkan. Menurut Lestari dan Triyono (2012), kesulitan siswa dalam memahami konsep nilai tempat adalah dalam memahami simbol matematika, belum lancar berhitung dan belum lancar dalam bahasa dan membaca. Nurmawati, dkk. (2000) menambahkan bahwa siswa sering salah dalam menuliskan lambang bilangan dan nama bilangan, kekeliruan terjadi ketika siswa menentukan nilai tempat dan nilai angka, dan kesalahan menuliskan lambang bilangan berdasarkan nilai tempat. Kesalahan ini terjadi karena dimungkinkan siswa mengalami kesulitan dalam memahami konsep nilai tempat. Konsep nilai tempat memerlukan pemahaman dalam integrasi dari konsep pengelompokan sepuluh dengan pengetahuan prosedural mengenai bagaimana suatu himpunan dicatat dalam skema nilai tempat, bagaimana bilangan ditulis dan bagaimana bilangan tersebut diucapkan (Van de Walle, 2008).

\section{METODE}

Penelitian ini menggunakan pendekatan kualitatif yaitu analisis hasil kinerja siswa pada materi nilai tempat. Instrumen yang digunakan berupa tes uraian tertulis dengan soal-soal tes berasal dari buku paket sekolah. Subyek penelitian ini adalah siswa kelas I berjumlah 38 siswa di salah satu SDN di Bandung Jawa Barat, Indonesia. Penelitian dilakukan seperti berikut. Pertama, peneliti melakukan prediksi jawaban soal yang akan muncul pada siswa mengenai bilangan romawi. Kedua, mengumpulkan data hasil jawaban siswa. Ketiga, menganalisis jawaban dengan prediksi guru. Keempat, menganalisis kesulitan siswa terhadap materi nilai tempat. 


\section{HASIL DAN PEMBAHASAN}

Dalam menganalisis jawaban siswa, sebelumnya telah dibuat beberapa prediksi kemungkinan jawaban baik jawaban yang tepat maupun kesalahan yang akan muncul pada siswa, yang selanjutnya dibandingkan dengan kenyataan yang ada di lapangan dan menganalisis kesulitan yang dihadapi siswa. Dalam melakukan observasi mengenai respon siswa terhadap soal latihan yang diberikan guru, ternyata jawaban siswa yang kebanyakan benar itu karena adanya keterlibatan guru dalam meminta siswa untuk memperbaiki jawaban yang salah terlebih dahulu sebelum masuk pada penilaian. Hal ini merupakan keterbatasan observer yang tidak dapat melakukan tindakan apapun atau tidak ikut campur dalam pembelajaran di kelas.

\section{Hasil Jawaban Siswa Soal Nomor 1}

Tujuh puluh dua $=\ldots .$.

Berdasarkan hasil observasi terhadap respon siswa mengenai hasil jawaban siswa pada soal Nomor 1, 27 siswa tepat dalam melakukan cara penghitungan maupun jawabannya. Siswa telah mampu menuliskan bahwa tujuh puluh dua jika menggunakan bilangan yaitu 72 . Siswa mengetahui bahwa $72=70+2$.

Selain itu, ditemukan beberapa kesalahan siswa dalam menjawab soal nomor 1 . Terdapat 10 siswa yang sesuai dengan prediksi yaitu tujuh puluh dua $=$ 702. Siswa telah tepat dalam penulisan bilangan yaitu bilangan 7 dan 2, hanya saja kesulitan yang dihadapi siswa tersebut ialah siswa belum memahami dengan benar aturan dalam nilai tempat sehingga siswa menuliskan sesuai yang siswa baca yaitu tujuh puluh $=70$ dan dua $=2$, yang akhirnya jika disatukan menjadi 702. Dengan begitu, siswa mengalami kesalahan dalam menuliskan bilangannya yang seharusnya 72 menjadi 702 . Respon lain mengenai kesalahan siswa yang sesuai dengan prediksi peneliti adalah tujuh puluh dua $=7102$. Terdapat lima siswa yang beranggapan bahwa tujuh $=7$, puluh $=10$, dan dua $=2$, sehingga jika disatukan menjadi 7102. Kesulitan yang siswa hadapi dapat disebabkan karena belum maksimalnya siswa dalam memahami secara tepat konsep nilai tempat.

Dari hasil analisis tehadap jawaban siswa pada Nomor 1, ternyata terdapat lima siswa yang jawabannya tidak ada diprediksi yang telah dibuat. Lima siswa mengerjakan tidak sesuai dengan soal yang diminta. Siswa sepertinya masih kesulitan dalam membaca, sehingga berdampak pula dalam mengisi jawaban 
tersebut. Selain itu, kesalahan-kesalahan yang dihadapi siswa secara umum dikarenakan kesulitannya dalam memahami konsep nilai tempat. Penempatan posisi dan cara membaca suatu bilangan yang tepat sangat memperlihatkan siswa yang paham dengan siswa yang tidak memahami materi nilai tempat.

\section{Hasil Jawaban Siswa Soal Nomor 2}

4 puluhan +6 satuan $=\ldots$.

Berdasarkan hasil observasi terhadap respon siswa mengenai soal Nomor 2 yang diberikan guru, jawaban tepat pada soal nomor ini sesuai dengan prediksi, yang pada kenyataannya sebanyak 20 siswa tepat dalam melakukan cara penghitungan maupun jawabannya. Siswa mampu memahami konsep nilai tempat dan menjumlahkannya. Siswa memahami bahwa 4 puluhan berarti 40, dan 6 satuan berarti 6 , sehingga 4 puluhan +6 satuan $=46$.

Berlanjut pada respon yang lainnya, ditemukan bahwa terdapat 24 siswa yang sesuai dengan prediksi yaitu 4 puluhan +6 satuan $=10$. Siswa menjawab 10, karena siswa hanya terfokus pada bilangan 4 dan 6 yang apabila dijumlahkan adalah 10. Kebanyakan siswa terlalu terburu-buru dalam menjawab, tanpa memperhatikan tiap soalnya. Selain itu, terdapat beberapa siswa yang belum lancar membaca, sehingga hanya melihat dari bilangannya saja. Padahal, dalam segi cara menghitung, siswa telah tepat. Hanya saja, keahlilan menghitung saja tidak cukup bagi siswa, melainkan memerlukan juga pemahaman matematika terhadap soal yang diberikan.

Respon siswa yang lainnya yang sesuai dengan prediksi ialah terdapat dua siswa yang menjawab 4 puluhan +6 satuan $=471$. Siswa menjawab itu berawal dari 4 puluhan yang berarti 410, dan 6 satuan berarti 61 , yang ketika dijumlahkan $410+61=471$. Siswa tersebut mengalami kesalahan konsep puluhan dan satuan. Siswa kemungkinan mengetahui bahwa puluhan berarti persepuluhan, tetapi siswa belum bisa menggabungkan dengan 4 puluhan, sehingga berakibat 410, begitupun dengan 6 satuan.

Dari hasil analisis tehadap jawaban siswa pada Nomor 2, ternyata terdapat satu siswa yang jawabannya tidak ada di prediksi yang telah dibuat. Siswa mengerjakan tidak sesuai dengan soal yang diminta. 


\section{E. KESIMPULAN}

Berdasarkan hasil penelitian ditemukan kesulitan umum siswa pada materi nilai tempat. Kesulitan terbesar siswa dalam materi nilai tempat adalah siswa belum memahami secara tepat konsep nilai tempat. Hal ini karena penempatan posisi dan cara membaca suatu bilangan yang tepat sangat memperlihatkan siswa yang paham dengan siswa yang tidak memahami materi nilai tempat. Selain itu, terdapat pula jawaban yang tidak terduga yang disebabkan siswa kurang teliti atau memang siswa tidak memahami materi nilai tempat, sehingga jawaban siswa asalasalan tanpa keterkaitan antara soal dan jawaban.

Melihat kondisi tersebut, ternyata guru bukan hanya perlu menyiapkan perencanaan seperti model/pendekatan/ metode/teknik/strategi pembelajaran, tetapi juga memprediksi kesalahan dan kesulitan siswa dalam soal latihan yang disajikan guru. Hal ini akan memudahkan guru dalam mengatasi kesulitan yang dihadapi siswa.

\section{DAFTAR PUSTAKA}

BSNP. (2006). Panduan Pengembangan Silabus Kurikulum Tingkat Satuan Pendidikan (KTSP) Sekolah Dasar (SD)/Madrasah Ibtidaiyah (MI). Jakarta: Depdikbud.

Lestari \& Triyono. (2012). Deskripsi Kesulitan Belajar Pada Operasi Penjumlahan dengan Teknik Menyimpan Siswa Kelas I SDN 3 Panjer Kecamatan Kebumen Tahun Pelajaran 2011/2012. Jurnal FKIP Pendidikan Universitas Sebelas Maret.Vol.1 No.2, hal 163-169 April 2012.

Nurmawati, dkk. (2000). Pembelajaran yang Berorientasi pada Konstuktivistik untuk Meningkatkan Pemahaman Konsep Nilai Tempat Bagi Siswa Kelas III SDN Kutohardjo II Rembang. [Online].Tersedia: http://lppm.ut.ac.id/htmpublikasi/21nurma. htm.

Ruseffendi, E.T. (1992). Materi Pokok Pendidikan Matematika 3. Jakarta: Depdikbud.

Sholeh, M. (1998). Pook-pokok Pengajaran Matematika di Sekolah. Jakarta: Departemen Pendidikan dan Kebudayaan RI.

Sumiaty, Encum dan Endang Dedy. (2015). Didactical Design of Junior High Schools's Mathematics Teaching Material Based on Learning Obstacles and Learning Trajectory. Proceedings International Seminar on Mathematics, Science, and Computer Science Education, hal. 78-83. 
Suwangsih, E. dan Tiurlina (2006). Model Pembelajaran Matematika. Bandung: UPI Press.

Van de Walle, J. (2008). Matematika Sekolah Dasar dan Menengah: Pengembangan Pembelajaran, Jilid 1 Edisi Keenam. Jakarta: Erlangga. 